DOI 10.4467/2543733XSSB.17.008.9983

ARTUR PATEK

Uniwersytet Jagielloński

\title{
TEKSTY FUNERALNE JAKO ŹRÓDLO HISTORYCZNE. PRZYCZYNEK DO BIOGRAFII ALEKSEGO WDZIĘKOŃSKIEGO, KONSULA RP W JEROZOLIMIE
}

\author{
Funeral Texts as a Historical Source. \\ A Contribution to the Biography of Aleksy Wdziękoński, the Polish Consul in Jerusalem \\ Summary
}

Funeral texts (obituaries, posthumous memories) are usually of a standard nature and show the deceased in a positive light. For this reason, they are marginalized as a research source. Wrongly, because they convey specific biographical information, such as the date of death and the age of the deceased, the place and time and the nature of the funeral ceremonies, and sometimes also the profession, circumstances of death, family name and others. The celebration of the last farewells may be an interesting contribution to the figure of the deceased, and in the case of people who have had their place in history, it also illustrates the state of feelings (patriotic, national, religious) of the local community. It seems that this additional sense, going beyond the usual rite of burial, focused on the funeral ceremony after the death of Aleksy Wdziękoński, the last consul general of the Second Polish Republic in Jerusalem.

Wdziękoński (1892-1946) ran the institution from June 1943 to January 1946. For the last months he acted in an unofficial capacity, as the United Kingdom withdrew recognition of the Polish Government in Exile. His death echoed in the emigration environments in Palestine, and the last farewell of the consul was attended by about $2,000-2,500$ people.

Keywords: Aleksy Wdziękoński, Consulate General of the Republic of Poland in Jerusalem, obituaries, obituary as a historical source

Słowa kluczowe: Aleksy Wdziękoński, Konsulat Generalny RP w Jerozolimie, nekrologi, obituaria jako źródło historyczne

Jaką wartość mają nekrologi i relacje z uroczystości pogrzebowych? W pewnym stopniu są panegirykiem na cześć zmarłego i mogą przywodzić na myśl znane z epoki staro- 
polskiej druki panegiryczne, ogłaszane z racji uroczystości weselnych czy pogrzebowych. Wiele z nich po prostu schlebiało ludzkiej próżności. Z tej przyczyny teksty funeralne jako źródło badawcze bywają marginalizowane i niedoceniane. Jeśli jednak wczytać się w ich treść, to okaże się, że przynoszą wartościowy materiał, np. do badań z zakresu genealogii i życia społecznego. Przekazują konkretne informacje, takie jak dokładna data zgonu i wiek zmarłego, miejsce i czas oraz charakter uroczystości żałobnych (świecki lub wyznaniowy), a bywa, że także zawód, okoliczności śmierci, nazwisko rodowe i in. Wiedząc, kto zamieścił nekrolog, zyskujemy podpowiedź, czy zmarły założył rodzinę, miał dzieci i czy przeżył współmałżonka, gdzie pracował, etc. Towarzyszące treści elementy graficzne (np. znak krzyża) i charakterystyczne określenia („świętej pamięci”, „błogosławionej pamięci”) pozwalają stwierdzić przynależność religijną. Inne detale sugerują sympatie polityczne (np. skrót „,tow.” [towarzysz] przed nazwiskiem). To wszystko ważne wskazówki w pracy historyka biografa.

Z kolei relacje z uroczystości pogrzebowych informują nie tylko o jej uczestnikach, ale również o zwyczajach funeralnych, mówią o charakterze lokalnej społeczności, o mentalności ludzi danej epoki, stanie ich uczuć (religijnych, narodowych etc.). Są dokumentem życia społecznego oraz punktem odniesienia do dalszych, bardziej szczegółowych badań. W okresach niewoli, a także na obczyźnie, pogrzeby znaczniejszych postaci pełniły rolę patriotycznych manifestacji, będąc ważnym elementem tożsamości narodowej.

Niniejszy artykuł stanowi próbę zastanowienia się, w jaki sposób można wykorzystać teksty funeralne jako źródło historyczne. Podejmując próbę odpowiedzi, chciałbym posłużyć się materiałami, które ukazały się po śmierci Aleksego Wdziękońskiego (1892-1946), ostatniego dyplomatycznego przedstawiciela Drugiej Rzeczypospolitej w Jerozolimie. Właściwe rozważania zostały poprzedzone krótkim z konieczności, ale niezbędnym, przedstawieniem podstawowych faktów z biografii dyplomaty oraz uwarunkowań, w jakich przyszło mu działać w Palestynie.

\section{Kontekst}

Aleksy Wdziękoński kierował Konsulatem Generalnym RP w Jerozolimie dwa lata i siedem miesięcy (15 czerwca 1943-30 stycznia 1946). Od lipca 1945 r. działał nieoficjalnie, ponieważ Wielka Brytania cofnęła uznanie Rządowi RP na Uchodźstwie.

Choć Konsulat w Jerozolimie mógł wydawać się egzotyczny, w rzeczywistości odgrywał znaczącą rolę. Po pierwszej wojnie światowej Palestyna, jako mandat Ligi Narodów, przypadła Wielkiej Brytanii, a Londyn zobowiązał się do budowy tam ,żydowskiej siedziby narodowej”. Wśród żydowskich imigrantów było wielu przybyszów z Polski i spora część zachowywała polskie obywatelstwo. O skali zjawiska świadczy fakt, że w latach 1919-1938 osiedliło się tam 137,1 tys. Żydów z naszego kraju, co stanowiło ponad 40\% ogółu imigrantów ${ }^{1}$.

Po wrześniu 1939 r. dołączyli do nich Polacy - uchodźcy wojenni. Tak się złożyło, że w tym niewielkim kraju, miejscu narodzin Starego i Nowego Testamentu, ukształtowało się jedno z najważniejszych skupisk polskiej emigracji niepodległościowej okresu wojny.

\footnotetext{
${ }^{1}$ Encyclopedia of Zionism and Israel, ed. by R. Patai, New York 1971, vol. 1, s. 538.
} 
Wprawdzie liczba cywilów mogła wydawać się stosunkowo niewielka (6718 osób według stanu na dzień 31 grudnia 1944 r.) $)^{2}$, ale trzeba pamiętać, że znaczący odsetek stanowili ludzie wykształceni, przedstawiciele przedwojennych elit, gdyż to oni w pierwszym rzędzie, w poczuciu zagrożenia, udawali się na uchodźstwo. W Ziemi Świętej przebywali także żołnierze Samodzielnej Brygady Strzelców Karpackich, 2. Korpusu Polskiego gen. Władysława Andersa i innych jednostek wojskowych. W sumie przez kraj narodzin Chrystusa przewinęło się kilkadziesiąt tysięcy Polaków, cywilów i wojskowych. Stworzyli tu namiastkę życia narodowego, swego rodzaju „Polskę w Palestynie” (własne organizacje, szkolnictwo, opieka społeczna, duszpasterstwo, prasa, życie polityczne i społeczne).

Gdy wybuchła wojna, w Palestynie działały dwa polskie konsulaty - w Jerozolimie i Tel Awiwie. Placówka w Świętym Mieście (siedzibie brytyjskich władz mandatowych) rozpoczęła działalność w 1923 r., a więc niedługo po utworzeniu mandatu. Dwa lata później jej rangę podniesiono, przekształcając w konsulat generalny ${ }^{3}$. Jego kompetencje rozciągały się również poza obszar Palestyny i obejmowały terytorium Transjordanii, a w różnych okresach także Cypr, francuski mandat w Syrii oraz Egipt i Irak. Konsulat nie zajmował się wyłącznie opieką nad obywatelami polskimi, w praktyce reprezentował państwo polskie wobec władz mandatowych oraz miejscowych ośrodków żydowskich i arabskich ${ }^{4}$. Znaczenie Konsulatu wzrosło w 1941 r., gdy decyzją Rządu RP objął zwierzchnictwo nad polskimi urzędami cywilnymi w Palestynie, w tym nad agendami opieki społecznej ${ }^{5}$. Oznaczało to, że Konsulat Generalny w Jerozolimie stał się najważniejszym przedstawicielem rządu (a więc placówką państwową) i politycznym zwierzchnikiem emigracji niepodległościowej w Ziemi Świętej.

Godność konsula pełnili doświadczeni pracownicy służby dyplomatycznej. Otton Sas-Hubicki (kierował placówką w latach 1925-1927) był wcześniej m.in. konsulem w Szanghaju i szefem wydziału konsularnego Poselstwa RP w Tokio. Jego następca, Tytus Zbyszewski (1927-1930), pracował jako konsul generalny w Lipsku. Kazimierz Zdzisław Kurnikowski (1931-1937) był konsulem w Nowym Jorku i Chicago, Witold Hulanicki (1937-1939) - kierownikiem Konsulatu Generalnego RP w Londynie, a Witold Korsak (1940-1943) szefem placówek w Essen i Düsseldorfie ${ }^{6}$. Ta polityka obsadowa świadczyła o pozycji, jaką zajmował jerozolimski Konsulat.

${ }^{2}$ Osoby pozostające w ewidencji Delegatury Ministerstwa Pracy i Opieki Społecznej Rządu RP (MPiOS) w Jerozolimie. Instytut Polski i Muzeum im. gen. Sikorskiego w Londynie (dalej: IPMS), A. 49/90, Raport Delegata MPiOS Kazimierza Jaroszewskiego, Jerozolima 27 I 1945 r.

${ }^{3}$ Akt ustanawiajacy etatowy Konsulat I klasy Rz.P. w Jerozolimie, „Dziennik Urzędowy Ministerstwa Spraw Zagranicznych Rzeczypospolitej Polskiej”, 1923, nr 5, poz. 58; Akt ustanawiajacy Konsulat Generalny Rz.P. w Jerozolimie, tamże, 1926, nr 1, poz. 9.

${ }^{4}$ Archiwum Akt Nowych w Warszawie (dalej: AAN), ,Wstęp do inwentarza zespołu akt Konsulatu Generalnego RP w Jerozolimie z lat 1926-1946”, oprac. A. Pałasiewicz (inw. nr 729, dostępny w czytelni naukowej AAN); W. Skóra, Stużba konsularna Drugiej Rzeczypospolitej. Organizacja, kadry i działalność, Toruń 2006, s. 104, 105, 889. Konsulat w Tel Awiwie rozpoczął działalność w 1932 r.

${ }^{5}$ Zob. protokół posiedzenia Rady Ministrów z 11 VI 1941 r., [w:] Protokoły posiedzeń Rady Ministrów Rzeczypospolitej Polskiej, red. nauk. M. Zgórniak, oprac. W. Rojek przy współpracy A. Suchcitza, t. 2, Kraków 1995, s. 377 (dok. nr 66).

${ }^{6}$ Biogramy w: Stownik biograficzny polskiej stużby zagranicznej 1918-1945, oprac. K. Smolana, vol. I, Warszawa 2007, s. 71-72, vol. III, Warszawa 2010, s. 137-139; Kto byt kim w II Rzeczypospolitej, red. J. Majchrowski przy współpracy G. Mazura i K. Stepana, Warszawa 1994, s. 97, 101; Polska służba zagraniczna po 1 września 1939 r., Londyn 1954, s. 108. 
Doświadczonym dyplomatą był również ostatni szef placówki, Aleksy Wdziękoński Urodził się w Kijowie, 13 sierpnia 1892 r., jako syn Aleksandra i Marii z Szymańskich. W owym czasie miasto to było jednym z najważniejszych ośrodków życia polskiego na dawnych kresach przedrozbiorowej Rzeczypospolitej. Polacy zaliczali się do miejscowej elity intelektualnej. Edukację przyszły konsul pobierał w rodzinnym Kijowie. W 1915 r. ukończył tamtejszy Instytut Handlowy, uzyskując tytuł kandydata nauk ekonomicznych. Po studiach został zmobilizowany do armii rosyjskiej, w której służył dwa lata, do września 1917 r. ${ }^{8}$ Następnie podjął pracę w Zarządzie Kolei Podolskiej Kijów-Żytomierz. Jesienią 1919 r., w obliczu ofensywy bolszewickiej, przedostał się do Polski i zaciągnął do Dowództwa Wojskowych Kolei Wołyńskich w Kowlu (listopad 1919-luty 1920). Później pracował jako referent w starostwie w Kowlu, a następnie w charakterze zastępcy referenta w starostwie we Włodzimierzu Wołyńskim.

We wrześniu 1921 r. Wdziękoński przeszedł do służby w Ministerstwie Spraw Zagranicznych. Praca ta dawała znacznie większe możliwości rozwoju. Pierwszą placówką, do której został skierowany, było nowo powstałe Poselstwo RP w Charkowie (ówczesnej stolicy Ukrainy). Można się domyślać, że przełożeni chcieli tu wykorzystać jego dobrą znajomość realiów ukraińskich. Początkowo pracował jako starszy kancelista w Wydziale Konsularnym, a potem w charakterze sekretarza konsularnego. W związku z reorganizacją placówki ${ }^{9}$, w listopadzie 1923 r. powrócił do kraju. Niebawem, w lipcu 1925 r., wysłano go do Strasburga, gdzie został attaché konsularnym w tamtejszym Konsulacie RP.

Ponieważ dał się poznać jako fachowiec, powierzano mu coraz odpowiedzialniejsze stanowiska w różnych placówkach. Po zakończeniu misji w Strasburgu był kolejno wicekonsulem w Tyflisie (obecnie Tbilisi, 1926-1928) ${ }^{10}$ i Bytomiu (styczeń-maj 1929), a następnie konsulem i kierownikiem Konsulatu RP we Wrocławiu (1929-1932), gdzie nie bez powodzenia podejmował wysiłki na rzecz wzajemnego zbliżenia i zrozumienia Polaków i Niemców ${ }^{11}$. Po opuszczeniu stolicy Dolnego Śląska otrzymał przydział do Zagłębia Ruhry, gdzie objął stanowisko szefa Konsulatu RP w Essen (1932-1933). Po powrocie do kraju, w styczniu 1934 r. został zastępcą naczelnika Wydziału Prasowego Departamentu Polityczno-Konsularnego MSZ. Obowiązki te pełnił do wybuchu wojny.

We wrześniu 1939 r. wraz z personelem ministerstwa opuścił Polskę, ewakuowany do Rumunii. Otrzymał etat w Ambasadzie RP w Bukareszcie, kierował polską YMCA, a w styczniu 1940 r. został dyrektorem wykonawczym Amerykańskiej Komisji Pomocy

${ }^{7}$ IPMS, A. 11.474/1/W, Karta personalna A. Wdziękońskiego; ibidem, A. 11.474/2/768, Teczka personalna; Biblioteka Polska POSK w Londynie (dalej: BPOSK), Archiwum Osobowe Emigracji; Stownik biograficzny polskiej stużby zagranicznej 1918-1945, vol. I, s. 122-123; R. Gelles, Dom z białym ortem. Konsulat Rzeczypospolitej Polskiej we Wrocławiu (maj 1920 - wrzesień 1939), Wrocław 1992, s. 77-89; R. Nir, Szkice z dziejów Polonii, Orchard Lake, MI 1990, s. 466-470; Życiorys Konsula Generalnego ś.p. Aleksego Wdziękońskiego, „Gazeta Polska” (Jerozolima), 1 II 1946, s. 2.

${ }^{8}$ Tak m.in. w karcie personalnej (IPMS, A. 11.474/1/W) oraz w pośmiertnym życiorysie w „Gazecie Polskiej” (1 II 1946). Z kolei Romuald Gelles podaje, jakoby Wdziękoński w czasie pierwszej wojny przeszedł „całą kampanię legionową". R. Gelles, op. cit., s. 77.

${ }^{9}$ Poselstwo RP w Charkowie zakończyło działalność na przełomie 1923 i 1924 r. i w jego miejsce utworzono Konsulat Generalny RP. J.J. Bruski, Między prometeizmem a Realpolitik. II Rzeczpospolita wobec Ukrainy Sowieckiej 1921-1926, Kraków 2010, s. 100-101.

${ }^{10}$ Początkowo w randze attaché konsularnego.

${ }^{11}$ Cyt. za: R. Gelles, op. cit., s. 88. 
Polakom. W owym czasie była to jedna z dwóch głównych organizacji zajmujących się opieką nad polskimi uchodźcami na terenie Rumunii ${ }^{12}$. Służba w Bukareszcie okazała się przejściowa, gdyż w listopadzie 1940 r. skierowano go do Bułgarii, gdzie w Poselstwie RP $\mathrm{w}$ Sofii objął urzędowanie w charakterze radcy ${ }^{13}$.

Również pobyt w Bułgarii nie trwał długo, bo już w 1941 r. Wdziękoński został przeniesiony do Stambułu i mianowany zastępcą kierownika Konsulatu Generalnego. Placówce nad Bosforem przyszło odegrać w latach wojny ważną rolę, gdyż przez Turcję biegł szlak ewakuacji Polaków z krajów bałkańskich na Bliski Wschód. Wykorzystując doświadczenie zdobyte w Rumunii, działał na rzecz pomocy polskim uchodźcom cywilnym i wojskowym. Aktywność tę dobrze oceniał konsul generalny w Stambule Zdzisław Szczerbiński, pisząc, że jego podwładny oddaje tu bardzo ustugi, zwłaszcza $w$ dziedzinie pomocy Polakom $^{14}$ i wyrażając wolę dalszej z nim współpracy. Od pewnego czasu krążyły bowiem pogłoski o przeniesieniu Wdziękońskiego na inną placówkę (wymieniano np. Dakar w Afryce). Również sam zainteresowany deklarował chęć pozostania nad Bosforem ${ }^{15}$.

Ostatecznie z dniem 1 czerwca 1943 r. skierowano go do Jerozolimy, mianując Konsulem Generalnym RP z pełnomocnictwami ,na obszar Palestyny (z wyłączeniem dystryktu Jaffy) i Transjordanii"'16. Zastąpił Jana Drohojowskiego, którego misja trwała zaskakująco krótko (od lutego do kwietnia 1943 r.). Drohojowski został odwołany do Londynu, gdzie czekała na niego funkcja sekretarza generalnego w Ministerstwie Informacji i Dokumentacji Rządu RP. Ranga placówki w Jerozolimie powodowała, że właściwie już od wybuchu wojny trwały wokół niej polityczne rozgrywki i dwukrotnie przez dłuższy czas stanowisko konsula pozostawało nieobsadzone ${ }^{17}$.

Oficjalnie Wdziękoński objął urzędowanie 15 czerwca 1943 r. ${ }^{18}$ Nominacja była awansem, ale sama misja wyjątkowo trudna. Pogarszało się międzynarodowe położenie Polski, co wpływało na nastroje wśród uchodźców. Pod koniec wojny do ofensywy przeszli komuniści (prosowiecki Związek Patriotów Polskich na Środkowym Wschodzie), próbując zdyskredytować środowiska wierne rządowi w Londynie. Polska emigracja w Ziemi Świętej była politycznie rozbita, gdyż na uchodźstwie znaleźli się ludzie związani zarówno z dawnym, jak i aktualnym obozem rządzącym (piłsudczycy i ,,antysanatorzy”). Prowadziło to do snucia intryg. Na domiar złego, w Palestynie nasilał się konflikt arabsko-żydowski. Zdarzały się incydenty między Polakami a Żydami. Problemy bytowe negatywnie wpływały na psychikę emigrantów, niektórzy wchodzili w kolizję z prawem ${ }^{19}$.

${ }^{12}$ Drugą był Centralny Komitet Obywatelski Pomocy i Opieki nad Uchodźcami w Rumunii. T. Dubicki, Działalność Amerykańskiej Komisji Pomocy Polakom na rzecz Uchodźców Polskich w Rumunii w latach 19391945, „Dzieje Najnowsze”, 1991, nr 4, s. 29, 34.

${ }^{13}$ IPMS, A. 11.474/2/768, Telegram szyfrowy do Polmission Bukareszt z MSZ, 29 X 1940 r.

${ }^{14}$ Tak w oryginale. Ibidem, Telegram szyfrowy konsula generalnego w Stambule Zdzisława Szczerbińskiego do MSZ, 1 III 1943 r.

${ }^{15}$ Ibidem, List A. Wdziękońskiego do Jana Wszelakiego z MSZ, 30 XII 1942 r.

${ }^{16}$ Ibidem, Akt mianowania, 12 V 1943 i 27 VI 1943 r.

${ }^{17}$ Sprawy te zasługują na osobne potraktowanie. O misji Drohojowskiego zob. J. Pietrzak, Polscy uchodźcy na Bliskim Wschodzie w latach drugiej wojny światowej. Ośrodki. Instytucje. Organizacje, Łódź 2012, s. 117-119; [J. Drohojowski], Jana Drohojowskiego wspomnienia dyplomatyczne, wyd. 3, Kraków 1972, s. $213-216$.

${ }^{18}$ IPMS, A. 11.474/1/W, Karta personalna A. Wdziękońskiego, s. 2.

${ }^{19} \mathrm{Na}$ osobną uwagę zasługuje działalność Wdziękońskiego jako konsula w Jerozolimie. Zagadnienie to wykracza jednak poza zakres niniejszego szkicu. 
Ta trudna sytuacja pogorszyła się po 5 lipca 1945 r., gdy Wielka Brytania cofnęła uznanie rządowi na obczyźnie i uznała władze w Warszawie. Jak donosił Tomasz Malicki z jerozolimskiej placówki Ministerstwa Spraw Wewnętrznych RP, obydwa konsulaty (w Tel Awiwie i Świętym Mieście) władze brytyjskie przemieniły na Misje Polskie, które wraz z Delegaturami MPiOS, MWRiOP i NIK weszły w skład tzw. Komisji Brytyjskiej20, czyli nowo powołanego Palestine Government Committee for Polish Affairs z siedzibą w Jerozolimie. Dawny konsulat nie przerwał czynności i nadal urzędował w tym samym miejscu $^{21}$. Działał jednak nieoficjalnie, a kontrolę nad instytucjami związanymi z rządem emigracyjnym przejęli Brytyjczycy. Równolegle jesienią 1945 r. działalność rozpoczęło przedstawicielstwo władz warszawskich ${ }^{22}$. W ten sposób przez pewien czas istniały w Jerozolimie dwa konsulaty i każdy uważał się za reprezentanta państwa polskiego.

Wdziękoński znalazł się w sytuacji wyjątkowo trudnej - stracił oparcie w mocarstwach anglosaskich, a władze, które reprezentował, przestały być realną siłą polityczną. Mimo to starał się kontynuować obowiązki służbowe. W gestii kierowanej przez niego placówki wciąż znajdowało się mienie ruchome konsulatu (w tym samochód służbowy) i akta ${ }^{23}$. Był jednym z głównych sygnatariuszy odezwy przedstawicieli władz i urzędów polskich w Palestynie; stwierdzała ona, że chociaż rzady państw obcych uznały rozszerzony komitet lubelski za rzqd polski, to jednak prawdziwym przedstawicielstwem Państwa i Narodu Polskiego jest konstytucyjny Prezydent i legalny Rzqd Polski w Londynie ${ }^{24}$.

W kolejnych miesiącach ciężka choroba ograniczyła aktywność konsula. Jak czytamy w notatce ks. prałata Tomasza Reginka (wikariusza generalnego biskupa polowego Wojska Polskiego na Bliskim Wschodzie i w Afryce), w czerwcu 1945 r. Wdziękoński ciężko zaniemógt na chorobę przewodu pokarmowego i żoładka, która przybrała charakter chro$n i c z n y^{25}$. Z innych przekazów wynika, że miał raka. Przez wiele miesięcy leżał obłożnie chory w swoim mieszkaniu służbowym w budynku konsulatu przy Nablus Road ${ }^{26}$. Skromne środki, jakimi dysponował, nie pozwalały na normalną kurację. W kosztownym leczeniu w szpitalu Hadassah (naświetlenia rentgenowskie) pomagał mu wspomniany ks. Reginek, a przekazane środki pochodziły z funduszy episkopatu USA ${ }^{27}$.

Niedługo przed śmiercią otrzymał Krzyż Komandorski Orderu „Polonia Restituta” III kl., przyznany dekretem Prezydenta RP, Władysława Raczkiewicza ${ }^{28}$. Miał również kilka odznaczeń zagranicznych, w tym belgijski Ordre de la Couronne IV kl., włoską komandorię z gwiazdą Orden dela „Corona de Italia”, rumuńską komandorię „Coroana României” oraz łotewską „Triju Zvaigžņu” (Trzech Gwiazd). Z krajowych wyróżnień posia-

${ }^{20}$ Biblioteka Jagiellońska w Krakowie, Archiwum Domowe Pawlikowskich (dalej: BJ, ADP), sygn. 11855 IV, Sprawozdanie Tomasza Malickiego z 8 X 1945 r., s. 5. Mowa o Delegaturach Ministerstwa Pracy i Opieki Społecznej, Ministerstwa Wyznań Religijnych i Oświecenia Publicznego oraz Najwyższej Izby Kontroli.

${ }^{21}$ Ibidem, s. 3.

${ }^{22}$ Pierwszym kierownikiem konsulatu generalnego (warszawskiego) w Jerozolimie został Edward Asz. B. Szaynok, Z historiq i Moskwa w tle. Polska a Izrael 1944-1968, Warszawa 2007, s. 57.

${ }^{23}$ Prawowita władza, „Biuletyn Wolnej Polski” (Tel Awiw), nr 8 (78), 22 II 1946, s. 1.

${ }^{24}$ Do Uchodźctwa Polskiego w Palestynie (dokument niedatowany), AAN, Akta Antoniego Pająka i jego rodziny, sygn. 19, s. 2-4; także w: IPMS, Kol. 660/4.

${ }^{25}$ R. Nir, op. cit., s. 466.

${ }^{26}$ BJ, ADP, sygn. 11855 IV, Sprawozdanie Tomasza Malickiego z 8 X 1945 r., s. 3; IPMS, Kol. 551, materiały biobibliograficzne dotyczące A. Wdziękońskiego, s. 6.

${ }^{27}$ R. Nir, op. cit., s. 466-467 (tu m.in. wykaz zabiegów leczniczych).

${ }^{28}$ W uznaniu zastug, „Gazeta Polska”, 14 I 1946, s. 1. Wdziękoński posiadał już Order „Polonia Restituta” V kl. 
dał m.in. Złoty Wawrzyn Polskiej Akademii Literatury, Medal Dziesięciolecia Odzyskanej Niepodległości i Złoty Krzyż Zasługi.

Zmarł w Jerozolimie, nad ranem 30 stycznia 1946 r. ${ }^{29}$ Został pochowany w polskiej kwaterze cmentarza katolickiego na wschodnim zboczu góry Syjon. Jego grób znajduje się wśród mogił polskich uchodźców wojennych ${ }^{30}$. W 2006 r., wraz z kompleksową renowacją kwatery, podjętą z inicjatywy Wydziału Konsularnego Ambasady RP w Tel Awiwie oraz Rady Ochrony Pamięci Walk i Męczeństwa z Warszawy, odnowiono także nagrobek Wdziękońskiego ${ }^{31}$.

\section{Nekrologi}

Odejście konsula odbiło się echem w polskiej społeczności w Palestynie. Gdy 31 stycznia 1946 r. ukazał się kolejny numer wydawanej w Jerozolimie „Gazety Polskiej”, całą pierwszą stronę dziennika wypełniły nekrologi i zawiadomienia o zgonie Wdziękońskiego. W sumie w numerze z tego dnia pojawiło się dziewięć takich not. Postać zmarłego przypominano na łamach pisma również w kolejnych dniach ${ }^{32}$.

Trzeba przypomnieć, że „Gazeta Polska”, która ukazywała się w latach 1941-1948, była dziennikiem informacyjnym Polaków na Bliskim Wschodzie i docierała także do skupisk poza Palestyną. Powstała z inicjatywy referatu prasowego konsulatu w Jerozolimie i przez cały czas uznawała władze RP na emigracji. W 1942 r. wydawanie gazety przejęło nowo utworzone Centrum Informacji na Wschodzie z siedzibą w Jerozolimie, placówka podległa Ministerstwu Informacji i Dokumentacji Rządu RP na Uchodźstwie. W ostatnim okresie (od grudnia 1947 r.), wskutek wyjazdu dużej części uchodźców, wychodziła $\mathrm{w}$ zmniejszonym formacie, odbijana na powielaczu ${ }^{33}$. W swoim czasie pismo to należało do najważniejszych tytułów polskiego uchodźstwa w Ziemi Świętej.

Zawiadomienia o śmierci konsula ukazały się także w londyńskim „Dzienniku Polskim i Dzienniku Żołnierza”, który stopniowo stawał się najpopularniejszym pismem polskiej emigracji niepodległościowej ${ }^{34}$. Odejście dyplomaty odnotował również wydawany w Jerozolimie żydowski i anglojęzyczny dziennik ,The Palestine Post” ${ }^{35}$.

$\mathrm{Z}$ punktu widzenia biografistyki znaczenie ma informacja, kto zamieścił nekrolog, gdyż mówi to o pozycji społecznej zmarłego. Wdziękońskiego żegnali m.in. Rada Naczel-

${ }^{29}$ „Gazeta Polska”, 31 I 1946, s. 1-3 (nekrologi). Błędna data śmierci (rok 1945) w: Encyklopedia Wrocławia, red. J. Harasimowicz, Wrocław 2000, s. 884; R. Gelles, op. cit., s. 89; Polska służba zagraniczna po 1 września 1939 r. s. 81.

${ }^{30}$ Lokalizacja grobu oraz tekst inskrypcji nagrobnej zob. A. Patek, Polski cmentarz w Jerozolimie. Polacy pochowani na cmentarzu katolickim na górze Syjon, Kraków 2009, s. 76-77 i plan na wklejce na końcu książki.

${ }^{31}$ Ibidem, s. 38-39.

${ }^{32}$ Życiorys zmarłego: 1 II 1946 (s. 2), relacja z pogrzebu: 3 II 1946 (s. 2), zawiadomienie o nabożeństwie żałobnym: 21 II 1946 (s. 2), sprawozdanie z posiedzenia Komitetu Uchodźców Polskich w Jerozolimie poświęconego pamięci Wdziękońskiego: 25 II 1946 (s. 4). Edycja pięciu nekrologów z 31 I 1946 r.: R. Nir, op. cit., s. $468-470$.

${ }^{33}$ Opis bibliograficzny: J. Kowalik, Bibliografia czasopism polskich wydanych poza granicami Kraju od września 1939 roku, t. 1, Lublin 1976, s. 182. Autor podaje błędnie, że pismo ukazywało się do 1947 r. IPMS, A. 11E/1230, „Sytuacja Polaków w Palestynie” (16 II 1948), s. 4; S. Lewandowska, Prasa polskiej emigracji wojennej 1939-1945, Warszawa 1993, s. 118; J. Pietrzak, op. cit., s. 240-243, 251-252.

34 „Dziennik Polski i Dziennik Żołnierza”, 6 i 7 II 1946 (dwa nekrologi podpisane „koledzy z MSZ”).

${ }^{35}$ Death of Polish Consul General in Jerusalem, „The Palestine Post”, 31 I 1946, s. 2. 
na Uchodźstwa Polskiego w Palestynie, Komitety Porozumiewawcze Organizacji Polskich w Jerozolimie i Tel Awiwie, Delegat Ministerstwa Pracy i Opieki Społecznej Rządu RP, Placówka Ministerstwa Informacji i Dokumentacji Rządu RP w Jerozolimie, zarząd Związku Federacyjnego Kombatantów Armii Polskiej, koledzy z Ministerstwa Spraw Zagranicznych i in. Podkreślano, że zmarły był reprezentantem prawowitego Rzqdu RP w Londynie i mimo choroby stał niezłomnie na stanowisku wierności Polsce Niepodległej ${ }^{36}$. Wyrażając żal po jego odejściu, pisano o bolesnym ciosie, jaki dotknat polskie społeczeństwo uchodźcze przez śmierć wielkiego patrioty ${ }^{37}$, którego praca i rady podtrzymywaty na duchu uchodźców polskich w chwilach dla Rzeczypospolitej najcięższych ${ }^{38}$.

Apelowano o liczny udział w uroczystościach żałobnych. Jak się wydaje, mogło tu chodzić nie tylko o godne oddanie ostatniej posługi, ale również zamanifestowanie uczuć patriotycznych w trudnym dla emigracji okresie. Ten dodatkowy sens uroczystości uzewnętrznił się rok później, gdy w rocznicę śmierci Wdziękońskiego w polskich ośrodkach uchodźczych (w Jerozolimie, Tel Awiwie i Jafie) odprawiono nabożeństwa za spokój jego duszy ${ }^{39}$. Nasz masowy udziat w modłach - czytamy w komunikacie Rady Naczelnej Uchodźstwa Polskiego w Palestynie - będzie spetnieniem nie tylko prostego obowiqzku chrześcijańskiego, ale przy tej okazji będziemy zanosić również modty o sprawiedliwość dla naszej Ojczyzny, o której Wolność nieustępliwa walka trwa nadal ${ }^{40}$.

Inaczej na śmierć konsula zareagował ukazujący się w Tel Awiwie komunistyczny „Biuletyn Wolnej Polski”. O ile brak nekrologu nie mógł zaskakiwać (chodziło przecież o politycznego przeciwnika), to już to, że na łamach pisma nawet nie odnotowano zgonu, było wymowne. Jedyna wzmianka pojawiła się po trzech tygodniach, na marginesie rozważań związanych z przejęciem mienia londyńskiej placówki przez przedstawicielstwo władz w Warszawie. Co znamienne - w notatce nie przywołano nazwiska zmarłego dyplomaty: „,De mortibus nihil nisi bene - o nieboszczykach nie mówi się, jeśli nie można mówić dobrze”. Dlatego też niech spoczywaja w spokoju okoliczności towarzyszqce ostatnim posunięciom reprezentantów b. rzqudu londyńskiego. Dość na tym, że przestała już istnieć szkodliwa fikcja , dwuch” (sic!) konsulatów”. Przestała istnieć możliwość wprowadzania $w$ bład nieświadomego obywatela przy pomocy pozorów władzy ${ }^{41}$.

Śmierć Wdziękońskiego osłabiała emigrację niepodległościową w Palestynie, a równocześnie wzmacniała pozycję przedstawicielstwa warszawskiego. Kierowanie placówką przejął dotychczasowy wicekonsul Jan Weber, ale nie miało to już większego znaczenia ${ }^{42}$. Niebawem Brytyjczycy przekazali większość mienia (w tym pomieszczenia biurowe) i akt

36 „Gazeta Polska”, 31 I 1946, s. 1 i 2 (nekrologi podpisane przez Radę Naczelną Uchodźstwa Polskiego w Palestynie oraz Komitet Porozumiewawczy Organizacji Polskich [KPOP] w Jerozolimie).

${ }^{37}$ Ibidem, s. 2.

${ }^{38}$ Ibidem (nekrolog podpisany przez KPOP w Tel Awiwie).

${ }^{39}$ Nabożeństwa odprawiono w kościele OO. Asumpcjonistów w Jerozolimie, Kaplicy Polskiej w Tel Awiwie i kościele św. Piotra w Jafie. „Gazeta Polska”, 29 i 30 I 1947, s. 2.

${ }^{40}$ Komunikat Rady Naczelnej Uchodźstwa Polskiego w Palestynie, „Gazeta Polska”, 29 i 30 I 1947, s. 4.

${ }^{41}$ Cyt. za: Prawowita władza (22 II 1946). Pismo ukazywało się w latach 1944-1947, sygnował je Związek Patriotów Polskich na Środkowym Wschodzie. Zob. J. Pietrzak, Sytuacja polityczna w Polsce w latach 1944-1947 w świetle „Biuletynu Wolnej Polski” - pisma Zwiazku Patriotów Polskich na Środkowym Wschodzie, „Przegląd Nauk Historycznych" (Łódź) 2008, nr 1, s. 105-126.

${ }^{42}$ IPMS, A VIII 3/3, Pismo Dowództwa Rejonu Terytorialnego Palestyna do Dowódcy Jednostek Wojska na Środkowym Wschodzie, 10 X 1946. 
konsulatu na ręce wysłannika prosowieckich władz w Warszawie, Romualda Gadomskiego, byłego członka Komunistycznej Partii Polski ${ }^{43}$. Oznaczało to właściwie koniec placówki. Trudno oprzeć się wrażeniu, że odejście dyplomaty przyspieszyło te rozstrzygnięcia. Ale doszłoby do nich i tak, i to raczej w nieodległej perspektywie.

W jaki sposób nekrologi przemawiają do historyka? Czy można je wykorzystać jako źródło badawcze? Na podstawie analizy wspomnianych materiałów można wyciągnąć następujące wnioski i spostrzeżenia:

(1) Mimo oczywistych różnic dotyczących doboru treści omawiane teksty zawierają konkretne informacje dotyczące: (a) różnych aspektów biografii, (b) charakteru uroczystości pogrzebowych, (c) miejsca pochówku oraz (d) nadawcy nekrologu, co z kolei (e) mówi o środowisku, z którym zmarły był związany. Przykładowo, dla historyka znaczenie mają dokładna data zgonu Wdziękońskiego ${ }^{44}$ oraz informacja, że przez ostatnie miesiące ciężko chorował (co tłumaczy, dlaczego w chwili śmierci miał tylko 53 lata). Na przynależność wyznaniową zmarłego wskazują m.in. miejsce uroczystości żałobnych (kościół OO. Dominikanów) oraz pochówku (cmentarz katolicki). Mamy również zwięzłą informację o uzyskanych odznaczeniach polskich i zagranicznych (z nazwy wymieniono dwa). Z kolei zapis, że zmarły dyplomata był reprezentantem prawowitego Rzadu RP w Londynie, świadczy o jego przekonaniach ideowych.

(2) Jak czytamy, Wdziękoński symbolizował majestat Rzeczypospolitej i nigdy nieprzedawnione prawa Narodu Polskiego do Niepodległośc $i^{45}$. Określenia brzmią w sposób podniosły (wręcz patetyczny), ale trzeba pamiętać, że zmarły był najwyższym ranga przedstawicielem konstytucyjnych władz Rzeczypospolitej na placówce w Palestynie. W sytuacji, w jakiej znalazła się emigracja niepodległościowa, postać dyplomaty nabierała dodatkowego znaczenia. Żegnano nie tylko człowieka, ale i pewien symbol. Dlatego akcentowano, że był on Bojownikiem o Wolność i Niepodlegtość Polski i do ostatniego tchnienia byt sercem i dusza $z$ nami w nieustęliwej walce o Wolność Rzeczypospolitej ${ }^{46}$, etc. Teoretycznie te i im podobne zwroty wpisywały się w konwencję nekrologu, który z założenia ma charakter pochwalny, ukazując postać zmarłego w pozytywnym świetle. W rzeczywistości niosły dodatkowy przekaz jak najbardziej aktualny dla tysięcy uchodźców, pozbawionych perspektyw powrotu do wolnej Polski.

\footnotetext{
${ }^{43}$ Jak donosił „Biuletyn Wolnej Polski”, w gestii ośrodka londyńskiego pozostały jednak m.in. depozyty obywateli polskich, okragłe pieczęcie i część aktów. Notatka w dziale „Komunikaty”: „Biuletyn Wolnej Polski”, nr 11 (81), 15 III 1946, s. 6. Gadomski od 1945 r. pełnił funkcję delegata rządu warszawskiego na Palestynę, Transjordanię, Syrię i Liban.

${ }^{44}$ Jeden nekrolog podaje nawet dokładną godzinę zgonu (szósta trzydzieści nad ranem), „Gazeta Polska”, 31 I 1946, s. 2.

${ }^{45}$ Sformułowania takie występują w nekrologu podpisanym przez Delegata Ministerstwa Pracy i Opieki Społecznej w Jerozolimie („Gazeta Polska”, 31 I 1946, s. 1).

${ }^{46}$ Nekrolog podpisany przez Radę Naczelną Uchodźstwa Polskiego w Palestynie (ibidem, s. 1).
} 
(3) Nadawcami nekrologów są działające w Palestynie polskie instytucje związane z Rządem RP na Uchodźstwie oraz ,grono kolegów z MSZ”. Brak zawiadomień podpisanych przez inne środowiska polityczne.

(4) W nekrologach zostało wymienionych łącznie 39 polskich organizacji i instytucji w Palestynie. Tym samym omawiane teksty stanowią interesujący materiał do badań nad życiem organizacyjnym polskiej emigracji w Ziemi Świętej po drugiej wojnie światowej. Są świadectwem aktywności tego środowiska.

(5) Uwagę zwraca brak zawiadomień podpisanych przez rodzinę, a także składanych zwyczajowo wyrazów współczucia najbliższym zmarłego, chociaż wiadomo, że Wdziękoński był dwukrotnie żonaty i miał dzieci ${ }^{47}$. Można domniemywać, że w chwili zgonu jego sytuacja rodzinna mogła być nieustabilizowana ${ }^{48}$.

(6) Z punktu widzenia polskich śladów w Ziemi Świętej znaczenie mają wzmianki o kaplicy w Tel Awiwie oraz polskiej części cmentarza katolickiego w Jerozolimie. Kaplica Polska znajdowała się w śródmieściu, przy Allenby Road 21, w wynajętym lokalu i została otwarta w maju 1941 r. Cmentarz zlokalizowany był na górze Syjon, nieopodal jerozolimskiego Starego Miasta, w 1941 r. wyodrębniono na jego terenie polską kwaterę jako miejsce pochówku uchodźców wojennych ${ }^{49}$.

\section{Ostatnie pożegnanie}

Nawet w biografiach ,wielkich ludzi”, które zwykle kończq się wraz z ich zejściem, ceremoniałowi odprowadzania na miejsce ich wiecznego spoczynku autorzy nie poświęcaja zbyt wiele uwagi ${ }^{50}$. Tymczasem celebracja ostatnich pożegnań może stanowić interesujący przyczynek do sylwetki zmarłego, a w przypadku osób, które zapisały się w historii, obrazuje również stan uczuć (patriotycznych, narodowych, religijnych, politycznych etc.) lokalnej, i nie tylko lokalnej, społeczności. Jak się wydaje, ten dodatkowy sens, wykraczający poza zwyczajowy obrzęd pochówku, ogniskowały w sobie uroczystości pogrzebowe po śmierci konsula Wdziękońskiego.

Ich przebieg można zrekonstruować na podstawie notatek prasowych. Najobszerniejsza relacja ukazała się na łamach „Gazety Polskiej” ${ }^{51}$. Wyszła spod pióra autora, który ukrył się pod kryptonimem ,St. Chr.” Prawdopodobnie był nim Stanisław Chruszczewski (Kempner-Chruszczewski, 1887-1964), przed wojną wieloletni naczelnik Wydziału Zdrowia w Zarządzie Miejskim w Łodzi. Po wrześniu 1939 r. wyjechał z kraju. Przedostawszy się przez Rumunię na Bliski Wschód, pracował w redakcji „Gazety Polskiej” oraz działał

${ }^{47}$ Z pierwszego małżeństwa miał syna, a z drugiego córkę. R. Gelles, op. cit., s. 78; IPMS, A. 11.474/1/W, Karta personalna A. Wdziękońskiego, s. 1.

${ }^{48}$ Według relacji Czesława Horaina (1904-1966), historyka i bibliografa od 1940 r. przebywającego w Jerozolimie, Wdziękoński w ostatnich latach życia miał pozostawać w nieformalnym związku. Nie udało się tej informacji zweryfikować. IPMS, Kol. 551, materiały biobibliograficzne dotyczące A. Wdziękońskiego, s. 5-6.

${ }^{49}$ [Z. Wyrzykowski], Polskie ślady na Ziemi Świętej (wywiad „, Gazety Polskiej” z ks. prałatem Tomaszem Reginkiem), „Gazeta Polska”, 27 VII 1944, s. 3; A. P a t e k, Polski cmentarz w Jerozolimie.

${ }^{50}$ G. P. Bąbiak, Funeralia narodowe. Pogrzeby patriotyczne Polaków w czasach niewoli (Eseje historyczne), Warszawa 2016, s. 13-14.

${ }^{51}$ Pogrzeb ś.p. Aleksego Wdziękońskiego Konsula Generalnego R.P. w Jerozolimie, „Gazeta Polska”, 3 II 1946, s. 2. 
w Komitecie Uchodźców Polskich w Jerozolimie. W 1947 r. powrócił do Polski i związał się z „Dziennikiem Łódzkim”52.

Zwięzłe, kilkuzdaniowe notki ukazały się w wychodzącym w Jerozolimie polityczno-literackim periodyku „W Drodze" ${ }^{53}$, w wewnętrznym biuletynie Stronnictwa Narodowego pt. „Myśl Polska na Wschodzie”,54, w londyńskim „Dzienniku Polskim i Dzienniku Żołnierza" ${ }^{55}$ oraz na łamach wojskowego ilustrowanego dwutygodnika „Parada”, sygnowanego przez Wydział Informacji i Oświaty Dowództwa Armii Polskiej na Wschodzie"56. Ten ostatni materiał zasługuje na uwagę, ponieważ zawiera dwie fotografie z uroczystości żałobnych. Na jednej widać kondukt przed gmachem Konsulatu RP w Jerozolimie, druga uchwyciła moment wprowadzenia trumny ze zwłokami do kościoła. Krótką relację z pogrzebu (cztery akapity) zamieścił również anglojęzyczny „,The Palestine Post”, ${ }^{\text {, }}$, co wskazywało, że śmierć konsula została zauważona także poza polskim środowiskiem.

Ceremonia pogrzebowa odbyła się w czwartek, 31 stycznia 1946 r. „The Palestine Post” i „W Drodze” szacowały, że wzięło w niej udział około 2000 osób. Wyższą liczbę uczestników, „ponad dwa i pół tysiąca”, podawał korespondent „Gazety Polskiej”. Uroczystości rozpoczęły się o godz. 10.00 w kościele OO. Dominikanów przy Nablus Road, we wschodniej części Jerozolimy. Nieopodal, przy tej samej ulicy (pod numerem ósmym) mieściły się siedziby polskich urzędów i instytucji związanych z rządem na emigracji: konsulatu, Komitetu Uchodźców Polskich i in. ${ }^{58}$ Trumnę ustawiono na podwyższeniu pośrodku kościoła. Okryto ją państwowym sztandarem, a wartę honorową zaciągnęli wychowankowie Junackiej Szkoły Kadetów w Palestynie ${ }^{59}$.

Nabożeństwo żałobne odprawiono równocześnie przed ołtarzem głównym i dwoma bocznymi, co świadczyło z jednej strony o randze ceremonii, z drugiej o stosunku Kościoła do osoby zmarłego. Mszę pogrzebową prowadził ks. płk Tomasz Reginek w asyście księży polskich, a okolicznościowe kazanie wygłosił ks. kanonik Stefan Pietruszka, kierownik Katolickiego Duszpasterstwa Polskiego w Palestynie.

Do kościoła przybyli przedstawiciele polskich władz cywilnych i wojskowych związanych z rządem na emigracji, a także reprezentanci brytyjskich władz mandatowych,

${ }^{52}$ A. Kempa, M. Szukalak, Żydzi dawnej Łodzi. Słownik biograficzny Żydów lódzkich oraz z Łodziq zwiqzanych, t. III, Łódź 2003, s. 58.

${ }^{53}$ Śp. Aleksy Wdziękoński, „W Drodze”, 16 II 1946, nr 2 (64), s. 6. Pismo było wydawane w latach 1943-1946 przez Centrum Informacji na Wschodzie. J. K o w a $1 \mathrm{i}$ k, Czasopiśmiennictwo, [w:] Literatura polska na obczyźnie 1940-1960, red. T. Terlecki, t. II, Londyn 1965, s. 437.

${ }^{54}$ Zgon Konsula Generalnego R.P. w Jerozolimie, „Myśl Polska na Wschodzie”, nr 27, luty 1946. Pismo ukazywało się w latach 1943-1946, a jego redakcja mieściła się w Jerozolimie. J. Kowalik, Bibliografia, t. 2, s. 112.

${ }^{55}$ Pogrzeb ś.p. Wdziękońskiego, „Dziennik Polski i Dziennik Żołnierza”, 9 II 1946, s. 4.

${ }^{56}$ Ś.P. Aleksy Wdziękoński Konsul Generalny R.P., „Parada. Dwutygodnik ilustrowany Żołnierza Polskiego”, nr 5 (75), 24 II 1946, s. 14. Pismo było wydawane w Kairze w latach 1943-1947 i wyróżniało się dobrym poziomem graficznym. Koszta druku ponosiły władze brytyjskie. J. Kowalik, Czasopiśmiennictwo, s. 436; S. Lewandowska, op. cit., s. 208; J. Mieroszewski, Parada „Parady”. Felieton rocznicowy, „Parada”, nr 8 (27), 16 IV 1944 , s. $8-9$.

${ }^{57}$ Funeral of Polish Consul General, „The Palestine Post”, 1 II 1946, s. 2.

${ }^{58}$ Adresy władz i instytucyj polskich w Palestynie, „Gazeta Polska”, 1 VII 1942, s. 4.

${ }^{59}$ Junacka Szkoła Kadetów w Palestynie została utworzona w 1942 r. Miała szkolić kadry dla wojska polskiego. W 1947 r. ewakuowana do Wielkiej Brytanii i w roku następnym rozwiązana. J. Draus, Oświata i nauka polska na Bliskim i Środkowym Wschodzie 1939-1950, Lublin 1993, s. 147-154, 173-174; Junacka Szkoła Kadetów 1942-1948, kom. red. E. Bąkała et al., Londyn 1972. 
Kustodii Ziemi Świętej, Łacińskiego Patriarchatu Jerozolimy, delegacje organizacji i stowarzyszeń niepodległościowych, przedstawiciele prasy, młodzież szkolna. Nieoficjalnie pojawili się również członkowie korpusu konsularnego, w tym konsulowie generalni Stanów Zjednoczonych, Francji, Hiszpanii, Czechosłowacji, Arabii Saudyjskiej, Iranu i Libanu, konsulowie Egiptu, Grecji, Iraku i Syrii, kierownik konsulatu Belgii oraz honorowi konsulowie Szwajcarii i Szwecji. Warto zauważyć, że spośród tych państw tylko trzy (Egipt, Hiszpania i Liban) wciąż uznawały Rząd RP na Uchodźstwie, toteż obecność delegacji zagranicznych miała dla polskiej społeczności duże znaczenie moralne ${ }^{60}$.

W uroczystościach wzięło udział wiele znaczących osób, m.in. Richard Massie Graves (przewodniczący Palestine Government Committee for Polish Affairs) ${ }^{61}$, Henryk Rosmarin (b. Konsul Generalny RP w Tel Awiwie), Antoni Pająk ${ }^{62}$ (prezes Rady Naczelnej Uchodźstwa Polskiego w Palestynie), Kazimierz Jaroszewski (kierownik Delegatury MPiOS), Wilhelm Krzysztoń (wiceprezes Centralnego Komitetu Uchodźców Polskich w Palestynie), Zygmunt Blenau (prezes Komisji Badawczej Ministerstwa Sprawiedliwości), ppłk Kazimierz Ryziński63 (dowódca Szkół Junaków i Młodszych Ochotniczek), ks. płk Teofil Wdzięczny (proboszcz Dowództwa Rejonu Terytorialnego Palestyna), ks. bp Sawa (zwierzchnik duszpasterstwa prawosławnego 2. Korpusu Polskiego), gen. Jan Tomasz Jur-Gorzechowski, dziennikarz i publicysta Zdzisław Broncell, prezesi Komitetów Uchodźców Polskich w Jerozolimie i Tel Awiwie - Stanisław Wiśniewski i Tadeusz Woydat ${ }^{64}$.

Po nabożeństwie wyruszył z kościoła kondukt żałobny. Cytowana „Gazeta Polska” podawała kolejne szczegóły: Otwierał orszak wieloletni kawas Konsulatu R.P. w Jerozolimie ${ }^{65}$, dalej niesiony byt Krzyż, a za nim wieńce $w$ szpalerach szkót polskich $w$ Jerozolimie i Ain-Karem ${ }^{66}$, za nimi postępowat Chór Uchodźców, dalej szło katolickie duchowieństwo

${ }^{60}$ Jak zauważył autor notatki zamieszczonej w „Myśli Polskiej na Wschodzie” (nr 27, luty 1946): udziat całego Korpusu Konsularnego oraz członków Rzqdu Palestyńskiego w pogrzebie świadczył wymownie jak moralnie silna pozycję ma prawdziwa Polska na świecie. Nawet najbardziej niechętnie do Polaków nastawieni przekonali się naocznie, jak agenci moskiewscy, chociaż uznani formalnie przez obcych, nie sq uznawani przez Polaków.

${ }^{61}$ Komitet do spraw Polskich Rządu Palestyńskiego (Palestine Government Committee for Polish Affairs) został powołany przez władze brytyjskie w 1945 r., po cofnięciu uznania Rządowi RP na Uchodźstwie. Przejął nadzór nad polskimi placówkami w Palestynie oraz opiekę nad uchodźcami. United Nations Archives and Records Management Section, New York (dalej: UNA), UNRRA, S-1021-0151-13, „Information on Polish refugees in Palestine", 20 XII 1945, s. 3.

${ }^{62}$ Późniejszy premier Rządu RP na Uchodźstwie (w latach 1955-1965). Zob. Inwentarz Akt Antoniego Pajaka (Premiera Rzq̨du Rzeczypospolitej Polskiej na Uchodźstwie) i jego rodziny z lat 1919-2001, oprac. E. Kołodziej i B. Nowożycki, Warszawa 2008, s. 7-17.

${ }^{63}$ Przed wojną szef Wojskowego Instytutu Naukowo-Oświatowego (1938-1939). We wrześniu 1939 r. szef sztabu obrony Lwowa. Małopolski słownik biograficzny uczestników działań niepodległościowych 1939-1956, t. 9, Kraków 2003, s. 142-144 (oprac. T. Łaszczewski).

${ }^{64}$ Korespondent „Gazety Polskiej” wymienił z nazwiska 28 osób znaczących w życiu polskiej emigracji w Palestynie.

${ }^{65}$ Honorowy strażnik dyplomaty. Przez cały okres istnienia placówki był nim Adib Samara. J. Łazor, Brama na Bliski Wschód. Polsko-palestyńskie stosunki gospodarcze w okresie międzywojennym, Warszawa 2016, s. 94 oraz fot. na wkładce.

${ }^{66}$ W Ain Karem (obecnie część Jerozolimy) znajdował się zespół polskich szkół żeńskich: powszechna, gimnazjum i liceum oraz przedszkole. Ain Karem. Ośrodek polskich dziewczqt. Palestyna 1942-1947, oprac. I. Stypułkowska przy współpracy C. Pichety i K. Kindlein, Londyn 1988. 
świeckie i zakonne, i za nim niesiono odznaczenia śp. Konsula. Dalszq część orszaku żatobnego stanowili karawan z trumna $w$ otoczeniu warty honorowej J[unackiej] S[zkoły] $K$ [adetów]. Za karawanem postępowali rodzina zmarłego ${ }^{67} i$ Konsul Jan Weber ${ }^{68}$, nastęnie płk Marszałek ${ }^{69}$, biskup Sawa, duchowieństwo kościoła anglikańskiego oraz dwaj rabini obywatele polscy, również nieoficjalnie Korpus Konsularny oraz przedstawiciele naszych władz i urzędów, przedstawiciele Rady Naczelnej Uchodźctwa Polskiego, Komitetu Centralnego ${ }^{70}$, Komitetów Uchodźczych ${ }^{71}$, przedstawiciele Wojska Polskiego, oficerowie stużby czynnej i rezerwy, zwarte szeregi Mt[odszych] Ochot[niczek] i Junackiej Szkoły Kadetów. Zamykał orszak żałobny kilkusetosobowy, ustawiony w trójki pochód Uchodźctwa z Jerozolimy $i$ wszystkich ośrodków poza Jerozolima ${ }^{72}$.

Ostatnia część uroczystości odbyła się na cmentarzu katolickim na górze Syjon. Nad mogiłą, w imieniu władz cywilnych, wojskowych i duchowieństwa, głos zabrał prezes Rady Naczelnej Antoni Pająk. Charakteryzując zmarłego, stwierdził, że był on do ostatniej chwili swego życia wierny Najjaśniejszej Rzeczypospolitej, byt bojownikiem o całość, wolność i niepodległość Polski ${ }^{73}$. Grób pokryło kilkadziesiąt wieńców, wśród nich od Rządu RP w Londynie, ministra spraw zagranicznych (Adama Tarnowskiego), Wojska Polskiego, organizacji i towarzystw uchodźczych, szkół polskich i in. Przebieg ceremonii zakłócił deszcz i z części pożegnań musiano zrezygnować ${ }^{74}$.

Zwyczajowo w budynku konsulatu wyłożono księgę kondolencyjną. Pamięć Wdziękońskiego uczczono podczas plenarnego posiedzenia Komitetu Uchodźców Polskich w Jerozolimie w dniu 20 lutego 1946 r. W okolicznościowych mowach (wygłosili je prezes KUP S. Wiśniewski i konsul J. Weber) zauważono, że społeczeństwo uchodźcze poprzez masowy udział w pogrzebie dało wyraz niezłomnej wierności wolnej i niepodległej ojczyźnie $i$ jej władzom ${ }^{75}$. Słowa te w jakimś stopniu były na pewno podyktowane konwencja i zwyczajem. Z drugiej strony przebieg uroczystości żałobnych wskazywał, że starano się im nadać dodatkowy wymiar.

${ }^{67}$ Najbliższą krewną Wdziękońskiego, obecną na pogrzebie, była jego siostra, J. Jankowska, która służyła w oddziałach Pomocniczej Służby Kobiet w Egipcie. Funeral of Polish Consul General.

${ }^{68}$ Jan Weber (ur. 1901) pracował w konsulacie w Jerozolimie od 1938 r. Dwukrotnie, w 1940 i 1943 r., był p.o. kierownikiem placówki. AAN, ,Wstęp do inwentarza zespołu akt Konsulatu Generalnego RP w Jerozolimie...".

${ }^{69}$ Maksymilian Marszałek (1888-1970) - oficer WP. We wrześniu 1939 r. dowodził obroną przeciwlotniczą OK nr 1 w Warszawie. Później m.in. dowódca Rejonu Terytorialnego Palestyna Jednostek Wojskowych na Środkowym Wschodzie. W. K. Cygan, Oficerowie Legionów Polskich 1914-1918. Stownik biograficzny, t. III, Warszawa 2006, s. 107.

${ }^{70}$ Centralny Komitet Uchodźców Polskich w Palestynie z siedzibą w Jerozolimie, powołany w czerwcu 1945 r. „dla skoordynowania i scentralizowania opieki społecznej”. IPMS, A. 76/44, „Statut organizacyjny Uchodźstwa Polskiego w Palestynie" (bez daty).

${ }^{71}$ Komitety Uchodźców Polskich (KUP) w Jerozolimie i Tel Awiwie.

${ }^{72}$ Cyt. za: Pogrzeb ś.p. Aleksego Wdziękońskiego Konsula Generalnego R.P. w Jerozolimie. Pisownia oryginalna.

${ }^{73}$ Ibidem.

${ }^{74}$ Ain Karem. Ośrodek polskich dziewczat, s. 173 (także fot. z pogrzebu); notatka w „Gazecie Polskiej”, 25 II 1946, s. 4.

${ }^{75}$ [St. Ch.], Uczczenie pamięci Konsula Generalnego ś.p. Aleksego Wdziękońskiego, „Gazeta Polska”, 25 II 1946, s. 4. 


\section{Wnioski}

Na kształt i charakter uroczystości pogrzebowych wpłynął ówczesny kontekst polityczny. Zdecydowana większość uchodźców lokowała sympatie po stronie rządu emigracyjnego, tymczasem najbliższy sojusznik, jakim była Wielka Brytania, uznał prosowieckie władze w Warszawie. Brytyjczycy szacowali, że aż 98\% polskiej społeczności jest przeciwna obecnemu rzqdowi warszawskiemu i nie ma zamiaru wracać, dopóki reżim ten sprawuje tam władzę $e^{76}$. Na pozostanie na uchodźstwie decydowali się najczęściej mieszkańcy Kresów Wschodnich, po wrześniu 1939 r. deportowani w głąb ZSRR. Nie mieli możliwości powrotu do stron rodzinnych, gdyż zajęła je Moskwa. Wciąż mieli w pamięci przeżycia związane z niewolą sowiecką. O życiu na emigracji, poza niechęcią do komunizmu, mogła decydować także służba w 2 . Korpusie lub przedwojenna działalność polityczna. Posunięcia władz brytyjskich spowodowały wśród Polaków poczucie zawodu. Zadawano sobie pytania: Co dalej? Jak długo będą wypłacane zasiłki?

Znaczenie omawianych tekstów wykracza poza warstwę ściśle informacyjną. Obrazują one stan nastrojów wśród emigracji niepodległościowej w Palestynie. Mówią nie tylko o stosunku do zmarłego, ale charakteryzują również samo środowisko. Wskazują wartości wyznawane przez tę lokalną społeczność. Jak się wydaje, niosły one dodatkowe treści także dla współczesnych, pełniąc rolę ważnego przekazu wewnętrznego i zewnętrznego. Uwagę zwraca rozbudowana forma wielu nekrologów. Są dość obszerne, pojawiają się w nich sformułowania odwołujące się do uczuć narodowych (patriotycznych). To nie przypadek, że akcentuje się ,prawa Narodu Polskiego do Niepodległości”.

Nie można było otwarcie wystąpić przeciwko polityce Zachodu, który faktycznie odwracał się od niedawnego sojusznika. Nie sprzyjały temu uwarunkowania, niekorzystne dla polskiej emigracji. Znamienna jest tu powściagliwość, z jaką o wolcie Londynu i innych aliantów pisała wspomniana „Gazeta Polska”. Nie mogło być inaczej, gdyż podlegała brytyjskiej cenzurze ${ }^{77}$, co oznaczało, że treści niewygodne dla Anglii po prostu się nie ukazywały. W tej sytuacji pogrzeb przedstawiciela legalnego Rzadu Polskiego stał się pretekstem do manifestacji uczuć narodowych, a nekrolog zastąił treść, której inaczej nie można było wyartykułować. W polskiej tradycji znane jest pojęcie pogrzebu patriotycznego. W okresach trudnych politycznie (np. w czasie zaborów) pochówki szczególnie zasłużonych osób były emanacją patriotycznych postaw narodu, jakich w inny sposób Polacy nie mogli wyrazić. Elementy tej celebry dostrzegamy także (toutes proportions gardées) w odniesieniu do pochówku Wdziękońskiego.

Pierwsza rzecz, która zwraca uwagę, to skala uroczystości. Według palestyńskiej komórki UNRRA (Administracja Narodów Zjednoczonych do spraw Pomocy i Odbudowy), w grudniu 1945 r. przebywało w Palestynie 5654 polskich uchodźców, w tym 1568 w Jerozolimie i $2378 \mathrm{w}$ Tel Awiwie ${ }^{78}$. Oznacza to (jeśli pominąć małe dzieci oraz osoby chore i niedołężne), że w pogrzebie uczestniczył niemal co drugi uchodźca, a na pewno więcej, niż było ich wtedy w całym Świętym Mieście.

${ }^{76}$ UNA, UNRRA, S-1021-0151-13, „Notes concerning the support of Polish refugees in Palestine”, b.d. (prawdopodobnie koniec 1945 r.). Inne szacunki mówiły o poparciu rzędu 90\%. BPOSK, Rps 1279, Papiery Stanisława Rosmańskiego, Notatka, b.d., s. 3.

77 J. Kowalik, Czasopiśmiennictwo, s. 436.

${ }^{78}$ UNA, UNRRA, S-1021-0151-13, „Information on Polish refugees in Palestine”, 20 XII 1945, s. 1. 
O tym, że pożegnanie konsula zawierało szersze treści, przekonywały dalsze przesłanki: apele o liczny udział w uroczystościach żałobnych, oprawa ceremonii (dekoracja trumny biało-czerwoną flagą, wojskowa warta honorowa), obecność czołowych przedstawicieli emigracji, tłumny przemarsz konduktu ulicami miasta, podkreślanie wierności polskim władzom na emigracji. Temperaturę uczuć patriotycznych podkreślały emocjonalnie brzmiące komentarze prasowe: $w$ tym żałobnym momencie złaczyly się wszystkie polskie serca i skonsolidowaty się wszystkie polskie uczucia w jedno wielkie ukochanie Ojczyzny (,Gazeta Polska") ${ }^{79}$, [pogrzeb] stał się wielkq manifestacja solidarności narodowej uchodźctwa polskiego i był widocznym wyrazem panujacej wśród nas jedności, gdy idzie o obronę zasadniczych praw naszego państwa (,W Drodze”), odprowadzenie zwłok na wieczny spoczynek stało się wielkq manifestacja narodowa prawdziwych Polaków („Myśl Polska na Wschodzie"). Zgodnie z konwencją pogrzebu patriotycznego odejście Wdziękońskiego przedstawiano jako stratę dla dalszej walki uchodźctwa polskiego o całość, wolność i niepodległość Polski ${ }^{80}$.

Nieprzypadkowo w inskrypcji, jaką wyryto na nagrobku dyplomaty, znalazły się słowa: „zmarł w służbie dla Polski”»1. Charakterystyczne, że w większości omawianych nekrologów pojawiało się sformułowanie „Polski Cmentarz Katolicki na Górze Syjon”. To skrót myślowy. Chodzi o polską kwaterę cmentarza. W warunkach życia na uchodźstwie, bardziej niż w kraju, polskie groby miały znaczenie dla zbiorowej świadomości. Nie tylko utrwalały pamięć o korzeniach, ale również w jakiś sposób integrowały wspólnotę uchodźczą ${ }^{82}$.

\section{Bibliografia}

Materiały archiwalne

1) Instytut Polski i Muzeum im. gen. Sikorskiego w Londynie

A. 11.474/1/W - karta personalna A. Wdziękońskiego

A. 11.474/2/768 - teczka personalna A. Wdziękońskiego

A. 11E/1230 - MSZ, korespondencja z Palestyną (1947-1949)

A. 49/90 - Konsulat Generalny RP w Tel Awiwie

A. 76/44 - Rada Naczelna Uchodźstwa Polskiego w Palestynie

A VIII - Armia Polska na Wschodzie

Kol. 660/4 - kolekcja Stanisława Olszewskiego

2) Biblioteka Polska POSK w Londynie

Archiwum Osobowe Emigracji im. Bohdana O. Jeżewskiego

Papiery Stanisława Rosmańskiego, Rps 1279

3) United Nations Archives and Records Management Section, New York, USA

S-1021-0151-13 - UNRRA Displaced Persons Operation in Europe and Middle East

4) Archiwum Akt Nowych w Warszawie

Akta Antoniego Pająka i jego rodziny, sygn. 19

${ }^{79}$ [St. Ch.], Uczczenie pamięci.

${ }^{80}$ Zgon Konsula Generalnego RP. w Jerozolimie, „Gazeta Polska”, 31 I 1946, s. 3.

${ }^{81}$ Inskrypcja ta, w porównaniu z napisami na innych polskich grobach na tym cmentarzu, jest dość obszerna. Poza nazwiskiem i imieniem oraz dokładnymi datami życia zawiera również informacje o miejscu urodzenia i zgonu, wykształceniu, zajmowanym stanowisku oraz najważniejszych odznaczeniach.

${ }^{82}$ Zaduszki Polskie, ,Gazeta Polska”, 3 XI 1947, s. 2. 
„Wstęp do inwentarza zespołu akt Konsulatu Generalnego RP w Jerozolimie z lat 1926-1946”, oprac. A. Pałasiewicz (nr 729)

5) Biblioteka Jagiellońska w Krakowie

sygn. 11855 IV - Archiwum Domowe Pawlikowskich

Wydawnictwa źródłowe

Akt ustanawiajacy etatowy Konsulat I klasy Rz.P. w Jerozolimie, „Dziennik Urzędowy Ministerstwa Spraw Zagranicznych Rzeczypospolitej Polskiej”, 1923, nr 5, poz. 58.

Akt ustanawiajacy Konsulat Generalny Rz.P. w Jerozolimie, „Dziennik Urzędowy Ministerstwa Spraw Zagranicznych Rzeczypospolitej Polskiej”, 1926, nr 1, poz. 9.

Protokoty posiedzeń Rady Ministrów Rzeczypospolitej Polskiej, red. nauk. M. Zgórniak, oprac.

W. Rojek przy współpracy A. Suchcitza, t. 2, Kraków 1995.

Wspomnienia

[Drohojowski J.], Jana Drohojowskiego wspomnienia dyplomatyczne, wyd. 3, Kraków 1972.

Tytuły wykorzystanej prasy (współczesnej)

„Biuletyn Wolnej Polski” (Tel Awiw) 1946

„Dziennik Polski i Dziennik Żołnierza” (Londyn) 1946

„Gazeta Polska” (Jerozolima) 1942, 1944, 1946, 1947

„Myśl Polska na Wschodzie” (Jerozolima) 1946

„Parada. Dwutygodnik ilustrowany Żołnierza Polskiego” (Kair) 1944, 1946

„The Palestine Post” (Jerusalem) 1946

„W Drodze” (Jerozolima) 1946

Monografie, rozprawy, opracowania

Ain Karem. Ośrodek polskich dziewczq̨t. Palestyna 1942-1947, oprac. I. Stypułkowska przy współpracy C. Pichety i K. Kindlein, Londyn 1988.

Bąbiak G. P., Funeralia narodowe. Pogrzeby patriotyczne Polaków w czasach niewoli (Eseje historyczne), Warszawa 2016.

Bruski J. J., Między prometeizmem a Realpolitik. II Rzeczpospolita wobec Ukrainy Sowieckiej 19211926, Kraków 2010.

Cygan W. K., Oficerowie Legionów Polskich 1914-1918. Słownik biograficzny, t. III, Warszawa 2006.

Draus J., Oświata i nauka polska na Bliskim i Środkowym Wschodzie 1939-1950, Lublin 1993.

Dubicki T., Działalność Amerykańskiej Komisji Pomocy Polakom na rzecz Uchodźców Polskich w Rumunii w latach 1939-1945, „Dzieje Najnowsze”, 1991, nr 4, s. 25-38.

Encyclopedia of Zionism and Israel, ed. by R. Patai, New York 1971.

Encyklopedia Wrocławia, red. J. Harasimowicz, Wrocław 2000.

Gelles R., Dom z bialym orlem. Konsulat Rzeczypospolitej Polskiej we Wrocławiu (maj 1920-wrzesień 1939), Wrocław 1992.

Inwentarz Akt Antoniego Pajqka (Premiera Rzqdu Rzeczypospolitej Polskiej na Uchodźstwie) i jego rodziny z lat 1919-2001, oprac. E. Kołodziej i B. Nowożycki, Warszawa 2008.

Junacka Szkoła Kadetów 1942-1948, kom. red. E. Bąkała et al., Londyn 1972.

Kempa A., Szukalak M., Żydzi dawnej Łodzi. Słownik biograficzny Żydów łódzkich oraz z Łodzia zwiazanych, t. III, Łódź 2003.

Kowalik J., Czasopiśmiennictwo, [w:] Literatura polska na obczyźnie 1940-1960, red. T. Terlecki, t. II, Londyn 1965, s. 373-548. 
Kowalik J., Bibliografia czasopism polskich wydanych poza granicami Kraju od września 1939 roku, t. 1 i 2, Lublin 1976.

Kto byt kim w II Rzeczypospolitej, red. J. Majchrowski przy współpracy G. Mazura i K. Stepana, Warszawa 1994.

Lewandowska S., Prasa polskiej emigracji wojennej 1939-1945, Warszawa 1993.

Łazor J., Brama na Bliski Wschód. Polsko-palestyńskie stosunki gospodarcze w okresie międzywojennym, Warszawa 2016.

Małopolski stownik biograficzny uczestników działań niepodległościowych 1939-1956, t. 9, Kraków 2003.

Nir R., Szkice z dziejów Polonii, Orchard Lake, MI 1990.

Patek A., Polski cmentarz w Jerozolimie. Polacy pochowani na cmentarzu katolickim na górze Syjon, Kraków 2009.

Pietrzak J., Polscy uchodźcy na Bliskim Wschodzie w latach drugiej wojny światowej. Ośrodki. Instytucje. Organizacje, Łódź 2012.

Pietrzak J., Sytuacja polityczna w Polsce w latach 1944-1947 w świetle „Biuletynu Wolnej Polski” - pisma Zwiazku Patriotów Polskich na Środkowym Wschodzie, „Przegląd Nauk Historycznych” (Łódź) 2008, nr 1, s. 105-126.

Polska służba zagraniczna po 1 września 1939 r., Londyn 1954.

Skóra W., Stużba konsularna Drugiej Rzeczypospolitej. Organizacja, kadry i działalność, Toruń 2006.

Stownik biograficzny polskiej stużby zagranicznej 1918-1945, oprac. K. Smolana, vol. I, Warszawa 2007, vol. III, Warszawa 2010.

Szaynok B., Z historiq i Moskwq w tle. Polska a Izrael 1944-1968, Warszawa 2007.

Artur Patek, prof. dr hab., kierownik Zakładu Historii Powszechnej Najnowszej w Instytucie Historii Uniwersytetu Jagiellońskiego; zajmuje się m.in. historią Bliskiego Wschodu oraz dziejami Polaków w Ziemi Świętej w XX w. Ważniejsze publikacje: Wielka Brytania wobec Izraela w okresie pierwszej wojny arabsko-izraelskiej, maj 1948-styczeń 1949 (2002); Jews on Route to Palestine 1934-1944. Sketches from the History of Aliyah Bet - Clandestine Jewish Immigration (2008); Polski cmentarz w Jafie. Z dziejów Polonii w Izraelu (2016). 


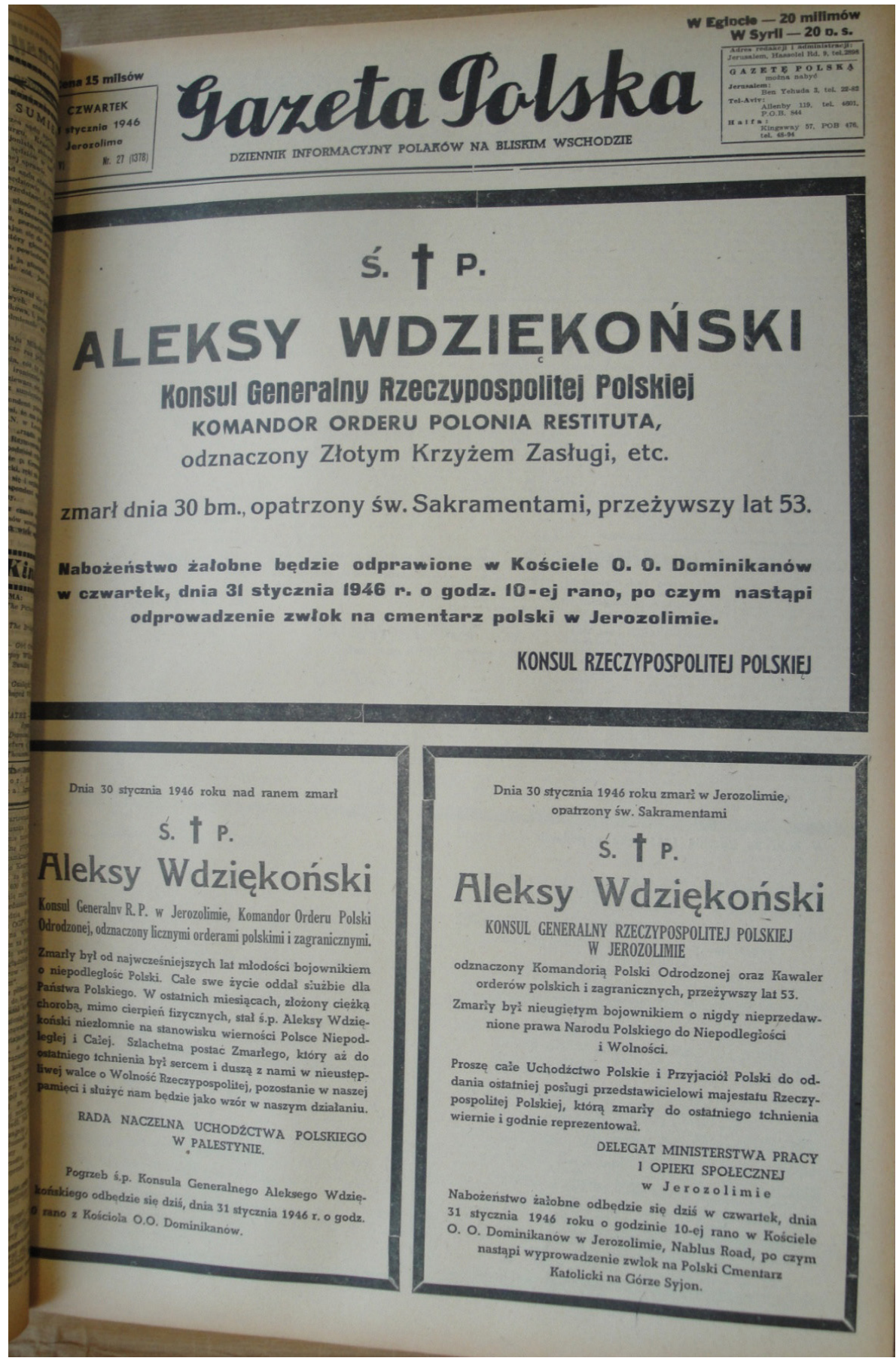

Fot. 1. Nekrologi, „Gazeta Polska”, 31 I 1946. 


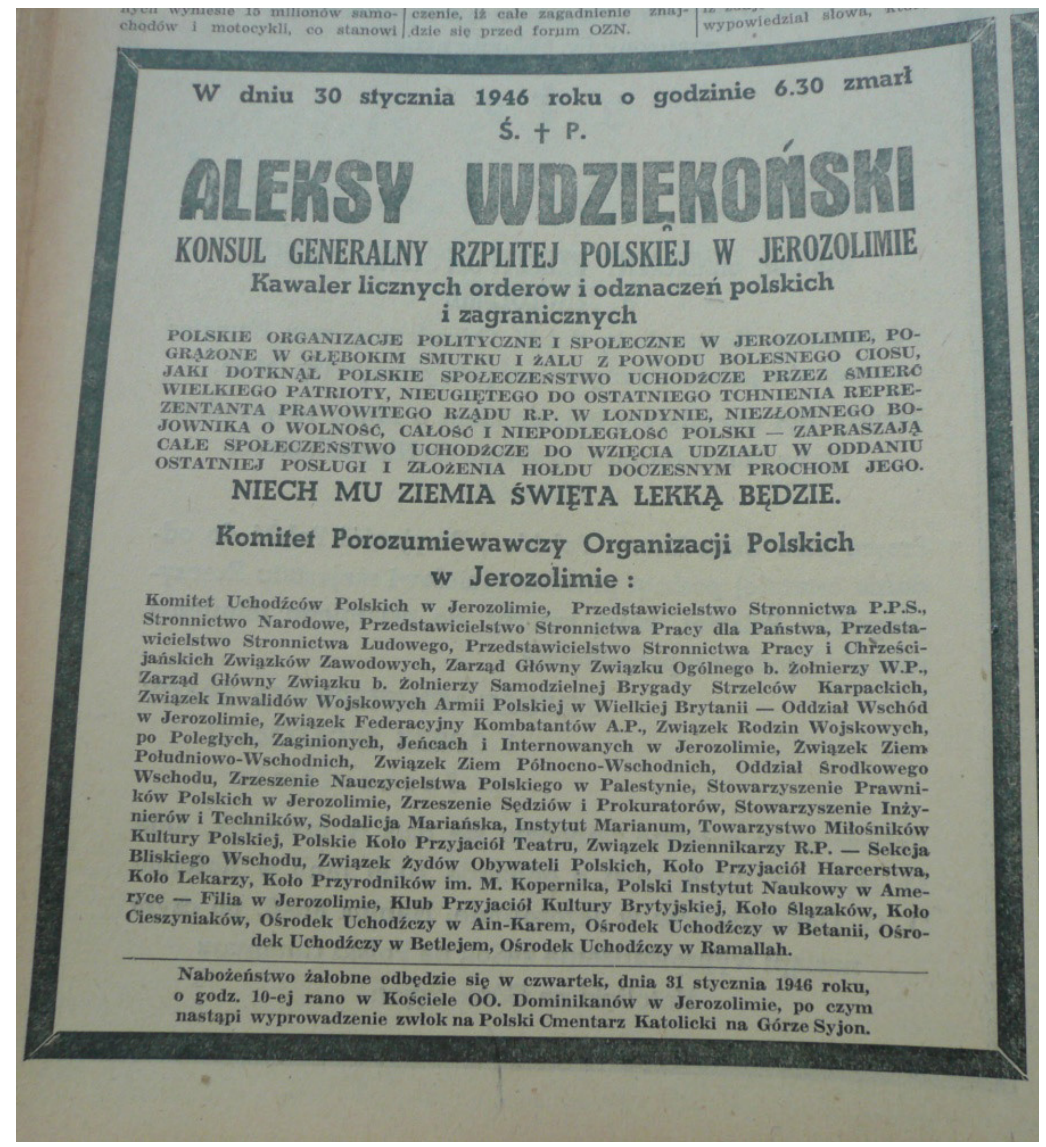

Fot. 2. Nekrologi, „Gazeta Polska”, 31 I 1946. 